\title{
Women as a Symbol of Motherhood, Love and Peace: The Manipur Narrative
}

\author{
Oinam Sareeta Devi \\ Assistant Professor, Kakching Khunou College, Manipur, India \\ Corresponding author: kasturba_kendra@yahoo.com
}

Received: 21 Aug, 2019

Revised: 18 Oct., 2019

Accepted: 29 Nov., 2019

\begin{abstract}
Loving, caring, sharing, life-giving, nurturing, etc. have been some of the adjectives often used to describe the essence of a woman. She has long been understood as someone who gentle and peace-loving by temperament. They have also been understood as influential in shaping the person of a child thereby determining who they become in their life to a great extent. Kofi Anan had also remarked: "For generations, women have served as peace educators, both in their families and in their societies. They have proved instrumental in building bridges rather than walls" Ever concerned with the wellbeing of their family and the society they live in at large; they always make very significant endeavors to secure inside the family as well the society those conditions which help everyone to live a life of dignity. Coming to the context of Manipuri women, they have a long tradition of being actively involved activities aimed at addressing socio-economic and political issues concerning their society. Apart from myths and legends, there were significant instances during the colonial period of Manipur that bear ample testimony to this. The tradition continued during the post-colonial period of the state as well. By doing so, they have played a great role in securing justice, peace and progress inside the society. The present paper is an attempt to examine the women of Manipur as the symbol of motherhood, love and peace inside the society.
\end{abstract}

Keywords: Peace-builders, women in peace-building, women and motherhood

"For generation, women have served as peace educators, both in their families and in their societies. They have proved instrumental in building bridges rather than walls"

- Kofi Anan

\section{Women's Nature}

Woman is a female human being. The word is usually reserved for an adult: girl is the usual term for a female child or adolescent (Wikipedia). The twentieth century is the Age of Woman: some day, it may be that it will back upon as the golden age, the dawn, some say, of feminine civilization. Because, 'Women' who are looking for satisfactory life, which is to be determined from within themselves, not from without by others. A woman is a symbol of self sacrifice and compassion. During pregnancy, women cheerfully carry the infant and feed it during nine months and suffer the severe pains of child-birth with joy. They are the one who brought up day and night with sleepless, eat less. For them many nightmares happen and suffered without any expression of discontentment. She attains

\footnotetext{
How to cite this article: Devi, O.S. (2019). Women as a Symbol of Motherhood, Love and Peace: The Manipur Narrative. Int. J. Peace, Edu. and Deve., 7(02): 101-107.

Source of Support: None; Conflict of Interest: None

(1) क
} 
satisfaction only in service and sacrifice, her prime concern is to provide solace and comfort to her husband and other members. Gandhi correctly said "Women are the embodiment of sacrifice and suffering". He realized the multifarious role of a woman and regarded women as "God Greatest Gift to Humanity". The biggest blessing bestowed upon women by God is the gift of giving birth to her off spring. She is the one who carry generations forward. Woman might look weaker physically in comparison to man but mentally and emotionally she is a way ahead of man. That is why, International Women's Day celebrate every year on March 8, to recognize the contribution of God's Supreme Creation 'Women' in making their world a beautiful space to live in. She plays various roles throughout her lifetime like a mother, daughter, sister or a wife.

The women are the seedbed of the nation; the house is the nursery and the country gather the harvest. They constitute half of the population in every society. They are the vital human resources in improving the quality of life. Women can be seen as an ideal wife, obedient and faithful home maker and above all a good mother. Without them, no family and no society cannot grow in a positive and creative direction. She acts as creator and promoter of peace in the family and in the society as well. It is evident that the women had occupied a very important place in every sphere of life. India is a country where women are worship as deities having supreme power and describe as 'Jagat Janani' where as in the state Manipur; women are symbolized by tradition as Mother figure in the society and placed them at a high esteem by the title, 'Eema'. According to ancient manuscripts and legends, the Manipuri women particularly the Meiteiswere always held traditionally in a high position. This is manifested by the mythical female characters like Eema Emoinu, Panthoibi and Konthoujam Lairembi whom the Manipuris consider as the Goddess of highest reverence. They are the role model of women's empowerment, free will and indomitable spirit. In other word; these mythological stories involving goddess were the origin of women's freedom and solidarity. Likewise, Goddess Leimarel Shidabi and Phoubi Lairembi showed their imitable style of negotiation at the time of family crisis and about economic prosperities of the families.

Likewise, the famous women legends viz, Khamnu, Thoibi, Pidonu and Tonu Laijing Lembi symbolized the true model of love, dedication, sacrifice and endurance, which remained immortal in every heart of the Manipuri's. And coming to a little closer to the present day we may recall the figures like Yairipok Thambalnu and Kanya, whose uncompromising attitudes, courage and sacrifices are still remembered by many in Manipur.

\section{Woman the Mother}

Mother are life givers, they are ones who are there to hold our hands when we take our first steps, they help us understand the world around us but most of all a mother plays the role of a child's teacher. "The first teacher of the child. The message she gives that child, the child gives to the world". A mother is a protector, disciplinarian and friend. She is selfless, loving human who sacrifice many wants and needs for the wants and needs of their children. Mother is virtually endless. Her journey of bringing up the child makes many sacrifices on the way and it is through those instances a child learns to grow up to be sensible, caring and compassionate towards other human beings. Mother gives us courage, joy and sacrifice and who teaches us to go forward in the life and fight all obstacle.

Napoleon Bonaparte the great French Emperor who said- "Give me good mothers and I shall give you a great nation". Mother has a major role to play in the physical, psychological and social development of a child. Parents have a significant role to play in inculcating, preserving and enhancing the values of children to assimilate in their family, which is one of the most important institutions for socialization and development of personality. Because, mother spends more time with children at home, She used to teaches children how to pronounce and speak, how to write and even arithmetic also. Always children saw their mother as their inspiration. Exactly the role of mother is not only child bearer but also an architect of her future children.

In other words, they are the builders of a nation. 


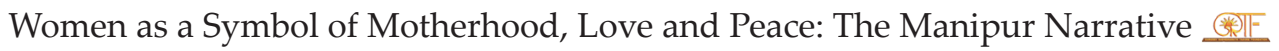

She is responsible for building the character of her children. She is the real educators, and hence, mother to the nation.

\section{Women as Promoter and Educator of Peace, Moral value and Spiritual value in the Family}

Women the promoter and messenger of peace, are an important members of the family and of the society. Peace is hardly found in the families without women playing their role as peace maker and cocoordinating the relationships among the members of the family young and old. Because of women and the constructive quality of the female mind could make the Home Sweet Home. And women made home as the importance place as our Heaven.

Women are defining as peace maker as well as peace promoter. In the broad sense we may called them as peace volunteer in the family as well as in the society. It is the duty of a mother to create an atmosphere of peace, love truth, kindness, patience etc. in the family. Mother as a peace volunteer has to train their children in order to work and act as peace lovers and peace promoters not only in the family, but also in the society. It is the duty of the mother to educate their daughters and make them fit to live in the society.

Mother always gives her supreme service and sacrificed her whole being for the family. She is also the one who takes all the blame and burden of the family on her shoulder and pacifies any problems and conflict through her wisdom and fervent prayers. In fact she wears a different facet to hide her woes and suffering without making herself known to others. Many women suffer in the hands of abusive husbands, sons, in-laws etc. and in such situations, she suffers alone silently and tries to settle and pacify everything within the family. Always she try to make a happy and peaceful family. Generally in Manipur Society, the woman has played a pivotal role as mediator among the family members. The day to day activities of a family are solely depended on the women who act in the role of grandmother, a granddaughter, mother-in-law, or even as a housewife, a daughter as so on. For instance a grandmother as a senior member could be the cementing force of the members of the entire families. Besides looking after the well being of the rest of the family members, they would extend all their knowledge and experience to keep the whole affairs of the family in a harmonious condition. There had been a long tradition of telling folk-tales and fables having moral value by the grandma to the young children as a means to build up their characters. The practice is still continuing in more or less in a changed form.

A mother or a mother-in-law is regarded as 'GrihaLakshmi' or the goddess of a family in every home in Manipur considering her age and experience. She will perform all household chores like washing, cooking, cleaning and other toiletries etc, in addition to small earning by doing small jobs to maintain the sound economic condition of the family. "Girls, there is much for you to learn. It is your function to use the needle and the scissors. You have to learn how to keep your home tidy. If there is order in the home, its influence will be felt outside and the village or town will reflect the state of the home. You will also have to learn to use money. You will be mothers one day, and your children's future will depend on you. It is not enough that you learn to read and write. You have to cultivate your mind too. For it is the mother who provides the real training for her child. Just as you develop your minds, so must you inform yourself of what is happening around you" (MK Gandhi). It is a common sight in families where the women mother engaged as well as trained the growing up daughter's to earning money through weaving, tailoring, \& Embroidery works, planting vegetables cultivations and particularly cooking etc. for there all round development as well as for their future livelihood.

Women's used to do Barta (fasting), Pujah (worship) and other forms of worships like visiting to temple, celebrating religious festival etc. for the welfare, prosperity and protection of their husband and children from evil spirits and difficulties. Mother teaches children to pray. It is lived and it is a legacy that is passed on to children.

There are certain codes of conduct in traditional family guiding Manipuri women in discharge of 
her functions-

$\odot$ not to wear dirty and soiled clothes,

$\odot$ not to leave and scatter overnight the leftover of the meal,

$\odot$ not to attend domestic work without washing hands after brooming,

$\odot$ not to plug vegetables from the courtyards while cooking,

$\odot$ not to hurt other sentiment and avoid lazy gossiping,

$\odot$ not to give away burning firewood directly from the 'Phungnal Lairu' when asked someone and

$\odot$ not to offer alms to beggars not more than twice a day.

Manipuri women particularly belongs to Meitei community always observe the above norms prescribe by 'Emoinu' goddess of wealth. Through observance of these norms, they are able to keep and maintained their family in peace and harmony.

It shows that from ancient past, Manipuri women have been the symbol of peace, prosperity, selfreliance, good and loveable mother. More or less in the Manipuri society, women play an important role as promoter of peace and moral strength among the family members. Sharing skill is such essential knowledge to sustain and improve the quality of life irrespective of the person, whether male or female was impacted by the mother or grandmother of the house. They tought- how to communicate with elders as well as younger member of the family and in the society in an informal way of education that is given by doing the work together, giving the chance of learning through demonstration and participation etc.

That is why, always women's is regarded as the first Guru or Teacher and home is the first 'School' of the child. Here is a saying - "The fruit of knowledge is from father and grandfather, the reserve wealth is from mothers and grandmothers". It shows the women's responsibility in the socio-economic position in the society also. It is well known that Manipuri women have been playing vital role in household activities since time immemorial. They work as one of the wheels of a bullock cart and tried to put household economy on the sound footing. Its glaring example is 'Eema Keithel' means 'Women's market'.

\section{Facets of Women in Peace Building Processes}

Due to the social, economic and political changes takes place from time to time, Manipuri women could not remain confined at home looking after the children and doing their house hold chores. They have to take more responsibilities physically, morally making their involvement in multifarious programme as a good mother's, teacher, administrator, labourer or even more as a social activist.

They are the maker and seekers, slowly increasing their efficiency, empower and empowering impeled them? How did they make the choices that they did? What inspired them to challenge, to innovate, to resist, to preserved, to excel, to fight, or to changeto somehow make a difference? Not only their own life, but to the lives of many others through their social or political engagement. It has been shown from earlier time that movements towards peace came through the influence of the women. Collective motive were more considered by Manipuri women in maintain peace. Their brave and courageous qualities in maintaining stable peaceful social order is well known. Some of the remarkable incidence mention may be made -

Myth Period: According to Meitei Mythology, 'Leimarel Shidabee' had two sons, 'Sanamahi' and 'Pakhangba'. The God father 'Khoyum Sidaba', in his tryst to find out his successor, he asked to his sons that any one of them who could go seven times around the world starting from the place of his throne and come back to the original spot, first would be his successor. Being known the decision of her husband, Leimarel Shidabee was worried and more concerned about younger son Pakhangba who was weaker than his elder son Sanamahi. She suddenly got an idea and advised her younger son Pakhangba to go seven times around his father's throne as it would be worth travelling seven times 


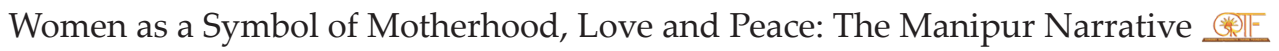

around the world and Pakhangba did so according to his mother's advice. In appreciation of the idea of Leimarel Shidabee, Khuyum Shidaba put his second son on the throne as his successor after completion of his trip of seven times around his throne. Sanamahi was enraged when he showed his younger brother Pakhangba is already on the throne when he returned back after completion of seven times around the Universe. He cried and challenged the decision. However, he was calm down tactfully by his father Khoyum Shidaba telling him that he would be the king in every household of the valley people and prayed along with his mother Leimarel Shidabee by virtue of his ability and power displayed. This showed the wisdom and presence of mind of the mother goddess and the ability to calm down the situation. Pakhangba became the successor of his father and Sanamahi became the king in every house of the 'Meitei's' who worshipped him as household deity.

Thus, Leimarel Shidabee has become the symbol of motherly love and affection with whose healing touch the young and innocent children can live in peace and harmony. It would be a role model of good and successful mothers to lead and nurture their children to a new horizon for the betterment of future generation.

Kings Period: During the reign of King, adult men were ordered to engage in war with neighbouring rulers, accompanying the king and in attending 'Lallup' in the palace. As a result, the male members of the family were not at home most of the time. So it was the women who peacefully carried out the responsibilities of the family including all the social, economic, cultural and domestic affairs. Women could also influence the political decision of the king in order to maintain peace and social stability in the state. A clear example, during the reign of King Chandrakirti, he ordered the men folk to accompany him for hunting of elephants during the harvesting.

British Colonial Period: Women's Movement happened during the British Period at two phases, the first in the year 1904 and the second in 1939. It is known as 'Nupi Lal', 'Women War'. Both the movement may be interpreted as the movements for promotion and maintenance of peace, wage by women of Manipur.

Women Movement- 1904: For construction of the residential building of British Officer, Assistant Superintendent which was burn down, the political Agent ordered the men-folk of Imphal to collect bamboos, thatches, reeds and other materials from Kabaw (Manipur Burma border) and also extract teak wood etc. Women considered it as a policy of the British to revive the Lallup system, which affect the social stability of the state. Therefore, Manipuri women had protested strongly against the decision of the British Authority by soughting slogan and entering in to the Residence of the Political Agent and Superintendent, and had demanded for the revocation of the order. Thus, the British could not persue its policy due to the reaction from the women folk.

Women Movement- 1939: Another notable social movement of women was in the year 1939. The main cause of the movement was scarcity of rice in the Khwairamband bazar, the main market of Imphal. The sudden outburst mainly due to economic problem which ultimately leads to social crisis and then political stability is also being affected. By the time, Manipuri women fought in a democratic way against the two authorities i.e. the British Political Agent and Maharaja of Manipur could save Manipur from social and economic instability by stopping the policy of export rice from Manipur.

Post Independence Period:

Nishabandhi: After the attainment of Statehood, 1970, the problems of Manipur increasing in different forms of issues, which had affected all the people, especially the womenfolk. In such situation, Manipuri women collectively form Nishabandhis force in the year 1975 to fight the evils created by alcoholism. Male folk consumed alcohol and disturbed the peaceful family life, in the community and consequently its surrounding atmosphere. And create frequent domestic violence against women and children resulting physical injury or death also. To overcome such social evil cause by alcoholism and restore normal situation in peaceful way, the women folk has started this movement against 
the intoxication. Their objective of movement was prohibition of liquor selling's, productions and consumptions in the localities. They have given warning to them not to continue their activities afterwards. And the violators of the directives were given punishment, by the 'Leikei' Women Force by imposing fines or penalties like hanging liquor bottle in their necks and asked them to walk on the roadside. These actions show that the womenfolk always try to promote peace in the family as well as in the society.

Meira Paibis: Manipuri Women Collective force known as 'Meirapaibee' emerges in 1980 to safe guard the youth from atrocities by the security. Due to implementation of different Acts and Rule by the Government had indirectly resulted in violation of human rights of the people in the name of maintenance of law and order in the state. Many persons including women and children suffered from immoral practices like sexual abuse, of rape, molestation, killing, disappearance persons etc. happen when army conducted search operations. In this armed conflict situation, they are the one who boldly came forward to face the challenging situation and safeguard innocent souls. Trying to maintain peaceful social atmosphere by guarding the whole night with flaming Torch to guard from excess committed by security personal and form a protective shield around their localities. They also act against men who indulge in drugs and alcohol disturbing the peaceful atmosphere of the locality.

Fast-unto-Death of Irom Sharmila: On $2^{\text {nd }}$ November 2000 the CRPF personal gun down 10 civilians at Malom, including 3 students and some government employee who were waiting for bus at bus stand. Against the Malom incident, a 32 year old woman Irom Chanu Sharmila undergone fast-unto-death from $4^{\text {th }}$ November 2000, protested by demanding immediate withdrawal of Armed Forces Special Power Act (AFSPA) 1958, which was imposed on September 8, 1980 to contain insurgency by the Government of India and State Government. Nobody has done such protest against the removal of AFSPA as Sharmila for bringing peace and normalcy in the turmoil state consecutively for 16 years against injustice. Even though her mission could not achieve, it shows the women of Manipur both young and old stand unite with courage for peace and defender of human right of the common people.

Kangla Fort Incidence: The ongoing armed conflict situation, the Meira Paibees and other women organization, appealed to the armed persons not to act and react in the public places from time to time. All the time, they tried to find out the means for solving the problems faced by Manipur people. Another heartbreaking incidence happen over and above burning issues like custodial deaths, fake encounters, and tortures in the custody of the army or paramitary forces etc, emerged. That, one woman, 'Thangjam Manorama Devi' of Bamon Kampu was arrested from her house at late night by issuing arrest memo to her family members on $10^{\text {th }}$ July 2004 by the $17^{\text {th }}$ Assam Riffles. Next morning she was found dead on the road side $4 \mathrm{~km}$. away from her house. Sentimental women's from different walks of life including Nishabandhis, Meirapaibees, Women vendors of Khwairamband Bazar spontaneously came out and started protest against the killing. And group of elderly women stripped off their clothes and stood naked at the main entrance of 'Kangla' Fort and shouted slogans by holding two scramming banners; in front of them and shout: "Indian Armyrapes us; Indian Army takes our Flesh" This shows how much women love peace and their motherland.

\section{CONCLUSION}

Manipuri women are known for their courage and sacrifices, valor, skill and active involvement in social, economic, political and cultural activities to whole over the world. She takes care of the family as a mother, wife, daughter, sister and daughter-inlaw. It is women, who have sustained the growth of the society and moulded the future of the nation i.e. 'Stri Shakti Jagaran' in Gandhian Principle. In today's complex scenario women have pivotal roles in every aspect of life. For controlling unwanted social situation, women play the endless role and come up in the scenario as facilitators, peace mediators and as negotiator. Gandhi said, "If we are to teach real peace in the world, we shall have to begin with children". At 
present, in the Global scenario, 'Licypriya Kangujam,' a seven year old girl of Manipur became the lead role Protestor against the 'Global Climate Change'. As World Child Peace Volunteer, her voice, "Save our Environment, Save our Planet, and Save our Future". It shows the social inherited responsibility to women, daughter of Manipur even today.

One mayask- Why Manipuri women are so forward strongly. Answer is 'Women Want Peace' when the peaceful atmospheres are disturbed, no one able to discharge their duties in a proper manner. Still necessary to reacquire our proud instinctive consciousness, which we are fully justified in having, of being the mother's of humanity; and having that consciousness. It may therefore be concluded, we need 'Miles to Go' and work together to increase more women's participation and influence in peace processes. It will intend to be an instrument for strengthening women efforts to promote inclusive peace processes and sustainable peace agreements that safeguard the right of both men and women in the year to come.

\section{REFERENCES}

Tombisana, Khumukcham, 2012. 'The Role of Women in Manipur', Rinda Publications.

Karam, Manimohan and Lal, Nupi. 2000. Women's War of Manipur.

Kalita, Shyamalima. 2019. Mother-A Child's first teacher $5^{\text {th }}$ September, 2019: In the Spotlight.

Phanjongbam, Tarapot and Ereipak, Eikhoigee. 2007. P.B. Book Distribution Private Limited, Manipur.

Oinam, Sareeta. 2009. Gandhi on Women: A Case study of Manipur, an unpublished Ph.D Thesis submitted to Manipur University, 2009.

Avarientos, Nora. 2017. Former Executive Director of World Vision Development Foundation speech on 'Being a mother: An important role of a woman, during PCEC Women's Commission Grand Rally, April 28, 2017.

Ksh, Bimola. 2005. 'Role of Women in Ushering Peace in Manipur', Seminar on Role of Women in Manipur in Peace-building organized by the Kasturba Gandhi Institute of Development; March, 2005. 
